\title{
13q Deletions detected by fluorescence in situ hybridization for diagnosis and prognosis of chronic lymphoproliferative neoplasms
}

\author{
V. V. Sitko ${ }^{1}$, J. A. Misharina ${ }^{2}$, J. M. Minchenko ${ }^{1}$, L. O. Poluben ${ }^{1}$, \\ O. O. Dmitrenko ${ }^{1}$, Y. O. Silaiev ${ }^{1}$, N. I. Kostyukova ${ }^{1}$, O. V. Tkachenko ${ }^{1}$, \\ A. O. Tovstogan ${ }^{1}$, V. M. Polyanska ${ }^{1}$, L. O. Lyashenko ${ }^{1}$, V. G. Bebeshko ${ }^{1}$ \\ ${ }^{1}$ State Institution «National Research Center for Radiation Medicine, NAMS of Ukraine» \\ 53, Melnikova Str., Kyiv, Ukraine, 04050 \\ ${ }^{2}$ Bogomolets National Medical University \\ 13, T. Shevchenko Boul., Kyiv, Ukraine, 01601 \\ Valentina-Sitko@yandex.ru
}

\begin{abstract}
Aim. Determination of deletion of the long arm of chromosome 13 in the patients with chronic lymphocytic leukemia, diffuse large B-cell lymphoma and multiple myeloma to provide prognostic assessments of Chronic Lymphoproliferative Neoplasms (CLPN) sub-variants progression, and early detection of therapy resistant cases and relapses of CLPN. Methods. Preparations of bone marrow cells from all patients $(\mathrm{n}=115)$ with CLPN were studied. Fluorescence in situ hybridization was performed using commercial test Vysis LSI D13S319 (13q14.3) Spectrum Orange/ Vysis LSI 13q34 Spectrum Green FISH probe kit (Abbott Molecular, USA). Results. The molecular cytogenetic investigations have revealed deletions of $13 \mathrm{q}$ in $38 \%$ of the patients with CLPN. We also present a clinical case where the deletion of $13 \mathrm{q}$ is detected along with other cytogenetic aberrations that significantly impair a disease prognosis. Conclusion. The analysis of deletions of the long arm of chromosome 13 is an important diagnostic and prognostic criterion, which assists to optimizes the treatment of the patients with CLPN.
\end{abstract}

Keyword s: chronic lymphoproliferative neoplasms, chronic lymphocytic leukemia, multiple myeloma, diffuse large B-cell lymphoma, 13q deletions, fluorescence in situ hybridization.

\section{Introduction}

Chromosomal abnormalities identified by fluorescence in situ hybridization (FISH) are known as prognostic factors for chronic lymphoproliferative neoplasms (CLPN) [1]. Among chromosomal abnormalities, deletion of the long arm of chromosome $13(13 q)$ is detected in more than 50 $\%$ of cases of chronic lymphocytic leukemia (CLL) [2] as well as in other B-cell malignancies [3], including de novo and transformed diffuse large B-cell lymphomas (DLBCL) $[4,5]$ and multiple myeloma (MM) [6].

Deletion of $13 \mathrm{q}$ is the most common cytogenetic abnormality in CLL [2]. This deletion represents early clonal aberration and suggests the loss of a tumor suppressor gene. The loss or inactivation of the tumor suppressor gene may be crucial for the development of CLL [7]. Deletion of 13q as a single aberration is associated with a good prognosis but additional abnormalities neutralize this favorable effect in CLL [8].

DLBCL has heterogeneous biological and clinicopathological characteristics. $30 \%$ of non-Hodgkin's lymphomas (NHL) and more than $80 \%$ of aggressive lymphomas are presented by DLBCL [9]. The aberrations of chromosome 13q are shown in different NHLs including both indolent and aggressive BNHLs. The data suggest that the loss of genetic ma-

(C) 2015 V. V. Sitko et al.; Published by the Institute of Molecular Biology and Genetics, NAS of Ukraine on behalf of Biopolymers and Cell. This is an Open Access article distributed under the terms of the Creative Commons Attribution License (http://creativecommons.org/licenses/by/4.0/), which permits unrestricted reuse, distribution, and reproduction in any medium, provided the original work is properly cited 
terial of the chromosome band $13 q 14$ may play an important role in the formation or development of a wide variety of mature lymphoid malignancies [10].

Multiple myeloma (MM) is a type of cancer formed by malignant plasma cells which show a complex of cytogenetic and molecular genetic abnormalities that not only essentially contribute to the pathogenesis of this disease but also reflect its prognostic heterogeneity $[11,12]$. The aberrations of chromosome 13 are found in approximately $50 \%$ of cases [13]. They are associated with aggressive clinical condition, especially in combination with other genetic abnormalities. The recent studies suggest a crucial role of chromosome 13 deletions as a prerequisite for the clonal expansion of myeloma cells $[14,15]$.

Our study was designed to evaluate the prevalence of deletion of the long arm of chromosome 13 in the patients with B-CLL, DLBCL and MM to provide prognostic assessments of the CLPN sub-variants progression, and the early detection of therapy resistant cases and relapses of CLPN.

\section{Materials and Methods}

Patients. 115 patients were included in the research: 30 patients with diffuse large B-cell lymphoma (DLBCL), 25 patients with B-cell chronic lymphocytic leukemia (B-CLL) and 60 patients with multiple myeloma (MM). All cases were diagnosed according to 2008 World Health Organization (Classification of Lymphoid Neoplasms) criteria [16]. The age of patients at diagnosis ranged from 5 to 79 years (the median is 59 years ). Three patients with DLBCL were children of 5, 10 and 11 years old. An average age for the patients with B-CLL was $59.60 \pm$ \pm 2.69 , for the patients with DLBCL $-47.30 \pm 3.61$, and $59.27 \pm 1.03$ for patients with MM. An average age of the patients with CLPN was $56.22 \pm 1.31$ years, among them $13(11.3 \%)$ were younger than 40 years. The substrate cells samples were obtained from 58 male and 57 female patients. The patients were informed about study objective and methods. Every patient has signed the informed consent.

Sample preparation and molecular cytogenetic studies. The research on cytogenetic abnormalities was performed on the 24-hour non-stimulated cul- tures of bone marrow cells. The cultivation of native bone marrow $(0.5 \mathrm{ml})$ for 24 hours was performed in $5 \mathrm{ml}$ culture medium RPMI-1640 («Sigma», USA) supplemented with $20 \%$ fetal calf serum («Sigma», USA) and $20 \mathrm{ml}$ of colchicines («Sigma», USA) for $2 \mathrm{~h}$ before fixation. The cell suspension was incubated in a thermostat at $37{ }^{\circ} \mathrm{C}$ for $24 \mathrm{~h}$. Upon completion of the cultivation, the hypotonic treatment of cells was carried out with heated up to $38{ }^{\circ} \mathrm{C}$ and prepared ex tempore $0.075 \mathrm{M}$ solution of potassium chloride for $20 \mathrm{~min}$ at $37^{\circ} \mathrm{C}(1 \mathrm{ml}$ of hypotonic solution to a precipitate obtained from $1 \mathrm{ml}$ of culture). $8 \mathrm{ml}$ of cooled holder (a mixture of methanol and glacial acetic acid in a ratio of 3:1) was added to the cell suspension. The samples were left at $+4{ }^{\circ} \mathrm{C}$ for $15 \mathrm{~min}$. Replacement of clamp was performed three times.

Fluorescence in situ hybridization. FISH was performed on the samples from all patients $(n=115)$ with the Vysis LSI D13S319 (13q14.3) Spectrum Orange/ Vysis LSI 13q34 Spectrum Green FISH probe kit (Abbott Molecular, USA) according to the manufacturer's protocol. The slides (prepared from the 24-hour non-stimulated culture) and probes were codenatured at $75^{\circ} \mathrm{C}$ with Vysis Hybrite and hybridized at $37{ }^{\circ} \mathrm{C}$ for 16 hours. In each case, at least 200 interphase nuclei with clear signals were analysed.

To determine the normal range for the test Vysis LSI D13S319 (13q14.3) Spectrum Orange/ Vysis LSI 13q34 Spectrum Green FISH probe kit at least 2000 interphase nucleus and 1000 metaphases of peripheral blood lymphocytes and bone marrow cells of ten healthy people of 16 to 67 years old (the average is $48.20 \pm 4.88$ ) were analysed. No $13 q$ deletion was found in the nuclei from apparently healthy donors (Fig. 1).

Cutoff levels for LSI D13S319/13q34 probe ranged $5 \%$ based on scoring of peripheral blood and bone marrow controls. Analysis was performed on the software and hardware complex CytoVision (Applied Imaging, UK) based on microscope Olympus BX51, Japan.

Statistical analysis. Statistical analysis of the results was performed using Statistica 6.0 and Microsoft Office Excel 2007. Significance of differences between groups, which were analysed, was assessed using $\chi 2$ criterion and the Fisher criterion point rec- 

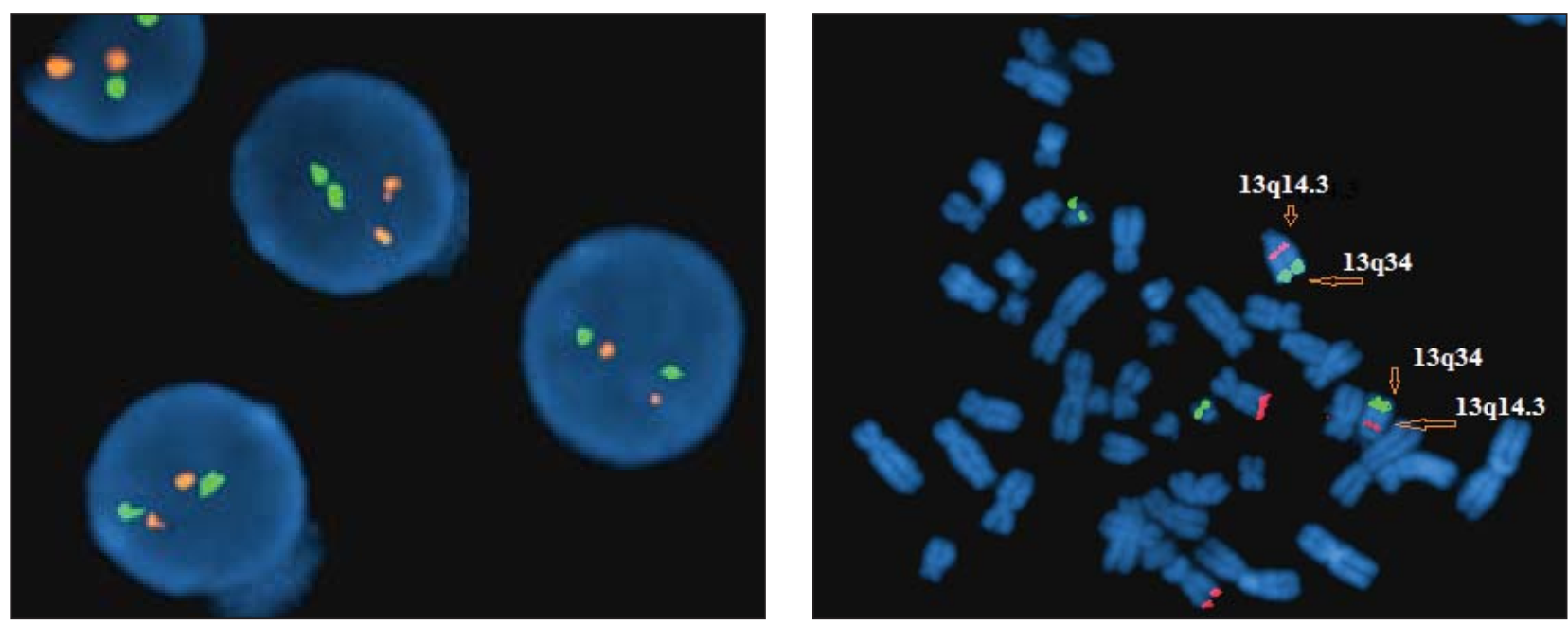

Fig. 1. The results of FISH on interphase nucleus and metaphases of peripheral blood lymphocytes and bone marrow cells of healthy donors using LSI D13S319/13q34 Probe kit. Two red (chromosome 13q14.3) and two green (chromosome 13q34) signals were registered in the normal cell nuclei

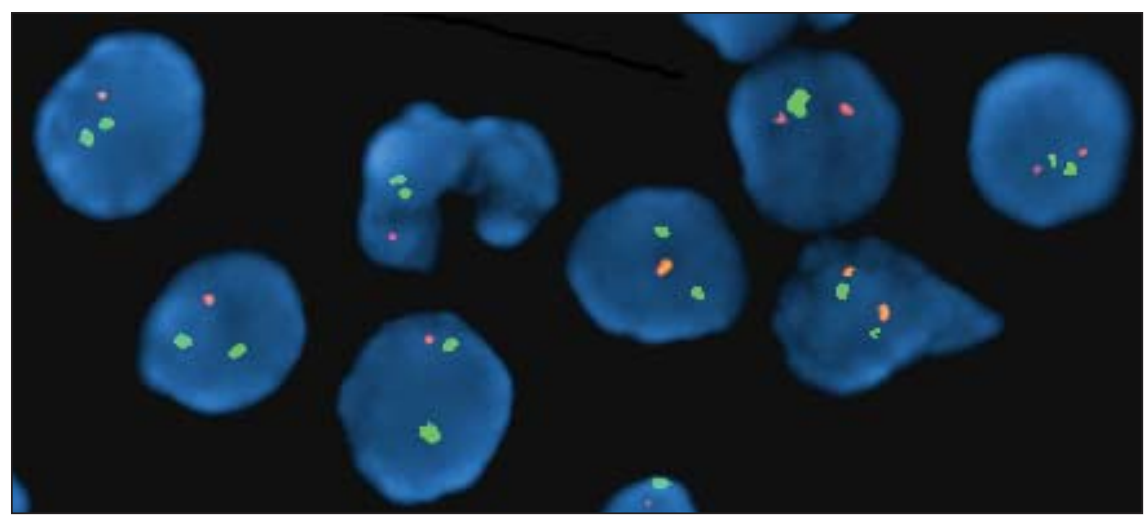

Fig. 2. The results of FISH on interphase nucleus of bone marrow cells of patient P. using LSI D13S319/13q34 Probe kit. Most of analysed cells showed one red (13q14.3) and two green (13q34) signals that corresponds to deletions of chromosome 13 in the region 13q14.3

ommended for the small group size. The difference was considered as statistically significant at $\mathrm{p}<0.05$. Determined parameters: mean, standard deviation, mean error and measurement error, minimum, maximum and median values, the maximum level of cells with abnormal set of signals $[17,18]$.

\section{Results}

Specific genomic abnormalities, such as loss of the $13 q 14$ and 13q34 regions, provide clinically significant prognostic information. They are known to be associated with prognostic impact in CLPN patients, which is important for appropriate choice of therapeutic protocol.

In the present study, we describe the frequency of deletions involving D13S319(13q14)/13q34 detected by FISH analysis in 115 patients with CLPN. Among the tested patients, $71(61.74 \%)$ had normal results, while $44(38.26 \%)$ had at least one genetic aberration. The analysis of interphase nuclei of bone marrow cells from the patients with CLPN showed that a single anomaly was registered in $30(68.18 \%)$ patients, and coexistence of two aberrations was revealed in 14 $(31.82 \%)$ ones. The FISH results are given in Table 1. 
In molecular cytogenetic study of bone marrow cells of the patients with B-CLL for each sample from 200 to 300 interphase nuclei were analysed, the total number of nuclei was 5640 (in average, $225.60 \pm$ $\pm 8.11)$, among them $5180(91.84 \%)$ of nuclei (in average, $207.20 \pm 11.20)$ were with normal distribution of signals 20x2G (D13S319, Spectrum Orange x 13q34, Spectrum Green). According to the results, the percentage of abnormal cells in average was $9.12 \pm$ \pm 2.2 . The number of nuclei with deletion of D13S319 varied in the range of $8-94$ with the average of $13.68 \pm 4.31$, the percentage of abnormal cells was $6.84 \pm 2.16$. The signals (10), which characterize the gene D13S319 deletion, were determined in ten patients with B-CLL. In 100 nuclei (1.77\% of the total number of analysed cells), an abnormal distribution of signals (1G) was determined. Thus, in five of 25 patients $(20 \%)$, the presence of $13 \mathrm{q} 34$ deletion has been found. Among 25 cases in the group with coexistence of two aberrations, three cases (12\%) had two aberrations. One of the patients had polysomy of chromosome 13 in 60 out of 200 analysed nuclei (30\%).

30 samples from the patients suffering from DLBCL were studied. A normal pattern of signals (20x 2G) was registered in 6332 (in average, $211.07 \pm$ \pm 9.72 ) cells, presenting $93.39 \%$. In 374 nuclei ( $5.52 \%$ of the total number of analysed cells) an ab- normal distribution of signals was determined. Overall, the aberrations of chromosome 13 were detected in 12 out of 30 (40\%) samples from the patients with DLBCL. Based on the interphase FISH analysis, six patients had D13S319 deletion; three of these patients had D13S319 deletion as a single abnormality, and three patients had additional delition (13q34). Thus, in eight out of 30 patients $(26.67 \%)$ Green hybridization signal was determined, indicating the presence of $13 q 34$ deletions. The number of nuclei with $13 \mathrm{q} 34$ deletion varied in the range from 16 to 60 with the average of $9.20 \pm 3.04$. Therefore, the percentage of abnormal cells was $4.60 \pm 1.52$. One of the patients had also trisomy in 40 out of 200 analysed nuclei $(20 \%)$ and the other one had polysomy in 50 out of 300 cells $(25 \%)$.

We have evaluated 60 samples from the patients with MM. The interphase nuclei were analysed, a total amount of nuclei was 14170 (in average 236.17 \pm $\pm 7.05)$, among them $12999(91.74 \%)$ in average $216.65 \pm 9.45$ with a normal distribution of thr signals (2Ox2G). 19 patients $(31.67 \%)$ had at least one genetic abnormality. Accordingly, the percentage of abnormal cells in average was $8.64 \pm 2.24$. 11 patients $(57.89 \%)$ had one abnormality; eight (42.11\%) had two abnormalities. The results showed the D13S319 deletion in 13 patients, abnormal distribu-

Table 1. 13q deletions in bone marrow cells in the patients with B-CLL, MM, DLBCL and BL

\begin{tabular}{|c|c|c|c|c|c|}
\hline No. & Literature & Country & Diagnosis & Tested patients & $13 \mathrm{q}$ deletion, $\mathrm{n}$ \\
\hline 1 & Chang et al. [19] & Korean & B-CLL & 16 & 9 \\
\hline 2 & Eid et al. [7] & Egypt & B-CLL & 20 & 16 \\
\hline 3 & Degheidy et al. [20] & USA & B-CLL & 54 & 33 \\
\hline 4 & Own data & Ukraine & B-CLL & 25 & 12 \\
\hline 5 & Caraway et al. [21] & Texas & DLBCL & 11 & 7 \\
\hline 6 & Nelson et al. [5] & Nebraska & BL & 90 & 38 \\
\hline \multirow[t]{3}{*}{7} & Havelange et al. [22] & Belgium & $\mathrm{BL}$ & 37 & 15 \\
\hline & & France & DLBCL & 12 & 6 \\
\hline & & & BL/DLBCL & 28 & 5 \\
\hline 8 & Own data & Ukraine & DLBCL, BL & 30 & 10 \\
\hline 9 & Durak et al. [23] & Turkey & MM & 50 & 27 \\
\hline 10 & Gao et al. [12] & China & MM & 60 & 38 \\
\hline 11 & Oh et al. [15] & Korea & MM & 929 & 218 \\
\hline 12 & Own data & Ukraine & MM & 60 & 18 \\
\hline
\end{tabular}


tion of the signals (10) was determined in 907 nuclei ( $6.40 \%$ of all analysed cells). The $13 q 34$ abnormality was observed in 13 out of 60 cases $(21.67 \%)$. Polysomy of chromosome 13 was present in one patient.

\section{Description of individual clinical case}

Patient P. (female), born in 1969, medical history N 6411, was examined in the Department of Radiation Heamatology of SI «National Scientific Center for Radiation Medicine of NAMS of Ukraine» in August 2004. Moderate leukocytosis and lymphocytosis were revealed in peripheral blood. The patient was observed by a haematologists and was examined for the second time in the Department of Radiation Medicine in May 2007. The test of peripheral blood cells from 07.05.2007 showed an increased number of white blood cells (CD $45^{+}-91 \%$, CD $19^{+}-91 \%$, CD $20^{+}-41 \%, \mathrm{CD} 22^{+}-91 \%$, CD $11 \mathrm{c}^{+}-$ $53 \%$, CD $5^{+}-55 \%$ ). Based on the clinical hematological data and assessment of the patient immune status, B-cell chronic lymphocytic leukemia was diagnosed. The patient was treated with Leukeran(Chlorambucil) $10 \mathrm{mg}$ daily, two cycles from 23-May-2005 to 07-Jun-2007 and from 27-Jul-2007 to 05-Aug-2007 (a total dose of chlorambucil was $260 \mathrm{mg}$ ) with shortlasting effect. The second line therapy was performed from 24-Dec-2007 to 25-Jun-2008, exactly, 6 cycles of chemotherapy according to FluCam protocol: Fludarabine $45 \mathrm{mg} / \mathrm{m}^{2}$ intravenous (IV) from the first to the third day, Campath $30 \mathrm{mg} / \mathrm{m}^{2} \mathrm{IV}$ from the first to the third day. The complete hematologic remission was achieved. The third line therapy was performed from 30-Apr-2010 to 20-Jul-2010; 3 cycles of chemotherapy according to COP regimen: Vincristine $2 \mathrm{mg}$ IV in the first day, Cyclophosphamide $400 \mathrm{mg}$ IV from the first to the fifth day, Methylprednisolone $64 \mathrm{mg}$ IV orally from the first to the fifth day, a complete disease stabilization was achieved. The forth line therapy was performed from 20-Jul-2011 to 31-Dec-2011: 6 cycles of chemotherapy according to OFC regimen: Ofatumumab $1000 \mathrm{mg}$ IV in first day, Fludarabine $22 \mathrm{mg}$ IV in 1-3 days, Cyclophosphamide $220 \mathrm{mg}$ IV in 1-3 days, a partial remission was achieved.

The disease progression and Fludarabine resistance were confirmed for the patient on 23-Oct-2012. In
April 2013, the samples of bone marrow cells were studied using interphase FISH in the Department of Hematology and Transplantology, SI «National Scientific Center for Radiation Medicine of NAMS of Ukraine». The presence of deletions of chromosome 13, namely, its regions 13q14.3 and 13q34, was studied using the samples hybridization with probe kit LSI D13S319 (13q14.3) Spectrum Orange / Vysis LSI 13q34 Spectrum Green (Abbott Molecular, USA). 200 interphase nuclei were analysed. Most (70\%) of analysed cells showed one red (13q14.3) signal and two green (13q34) signals, indicating the clonal nature of the tumor and the presence of deletions of chromosome 13 in the region 13q14.3. Other nuclei $(30 \%)$ showed two red and two green signals that corresponds to norm.

As a result of study, del (13q) was found in $70 \%$ of analysed cells. According to the literature, the chromosome 13 deletion can be a positive prognostic marker in the patients with B-CLL if no related structural aberrations and quantitative changes in other chromosomes were found. However, the FISH analysis revealed the following changes of chromosomes in the patient: gene TP 53 deletion - $47 \%$ (chromosome 17), deletion of chromosome 11 (11q22.3) $39 \%$, hiperaneuployidy of chromosome 14 (monosomy $-20 \%$, trisomy $-8 \%$ ), polyploidy of chromosome $16-18 \%$.

There were detected changes of chromosomes. The abnormalities of chromosomes 11, 13, 14, 16 and 17 may indicate unfavourable prognosis for the patient $\mathrm{P}$.

After our studies, the cytoreductive treatment of the patient was intensified with administration of immunotherapy (monoclonal antibodies such as Rituximab and Ibrutinib) in combination with chemotherapy. Despite the intensified treatment, the patient achieved only short-lasting effects and the diseases continued to progress. The diseases prognosis is unfavourable.

\section{Discussion}

This study evaluated 115 CLPN patients with chromosomal abnormalities via interphase FISH. The genetic abnormalities at CLPN are typically complex and represent a hallmark of the disease, many chro- 
13q Deletions detected by fluorescence in situ hybridization for diagnosis and prognosis of CLPN

mosomes are impacted in both number and structure. The conventional cytogenetic methods detect abnormal chromosomes approximately in 26-40\% of cases due to a low proliferative activity in vitro of B-cells, whereas FISH enables the detection of specific abnormalities in up to $86-98 \%$ of the cases [24, $25]$. The results of our research and the similar data of other authors are presented in Table 1.

In FISH analysis of the patients observed, the deletions of $13 q$ are detected in almost $35 \%$ of CLPN cases. Thus, the chromosome 13 deletions were found in 12 out of 25 patients with B-CLL, 10 out of 30 patients with DLBCL and 18 out of 60 patients with MM. The average percentage of deletion of $13 \mathrm{q}$ for the patients with CLPN was respectively $48 \%$, $33 \%$ and $30 \%$, that was slightly lower than described in the literature. In general, the results presented in Table 1 show a slight divergence between our data and results of other researchers. At the same time, among 60 patients with MM, the deletion in chromosome 13 was registered in 18 patients, which is significantly lower than Gao et al. [12] showed, they identified the deletion of $13 \mathrm{q}$ in 38 out of 60 patients with MM. In our study, the deletion of D13S319 locus located in 13q14 was detected in 29 out of 115 patients with del(13q), while the del(13q14) was determined in 26 out of 115 patients with CLPN. In the patients with B-CLL the deletion of $13 q 14$ was identified in 10 out of 25 patients, while deletion of $13 \mathrm{q} 34$ was presented only in five out of 25 patients. Conversely, testing 60 patients with MM showed the deletion of $13 \mathrm{q}$ in 18 patients: deletions of $13 q 14$ and $13 q 34$ were identified in 13 analysed cases. In the patients with MM, the presence of deletion of $13 q$ is a poor prognostic factor, while it is related to good prognosis in B-CLL.

Consequently, according to the analysed in detail research results, the following aspects are worth noting. In the case of B-CLL patients, our data are comparable with those received by Chang et al. [19], though they refer to a smaller number of patients examined. A little higher percentage of the chromosome 13 abnormalities is shown in the researches of Degheidy et al. [20]. Perhaps, it is connected with the fact that in this work peripheral blood cells were studied, whereas in our study - bone marrow cells. The work of Eid et al. [7] showed a significant number of the patients with the chromosome 13 aberrations. However, in this work the FISH analyses were conducted following three chemotherapy courses. Our patients were examined to the background therapy, at the initial examination. Accordingly, the FISH analysis was carried out at different stages of diagnostics and treatment.

As regards patients with the DLBCL, obviously, the distinctions are connected with a small group of examined patients: Caraway et al. [21] (11 patients $63 \%$ ) and Havelange et al. [22] (12 patients - 50\%). Nelson et al. [5] examined patients with Burkitt's lymphoma, which in essence is an aggressive lymphoma among non-Hodgkin's ones.

As for the MM patients, our data are consistent with the data received by $\mathrm{Oh}$ et al. [15], though a considerably larger number of patients were analysed in their work. In the work of Gao et al. [12], the authors used purified plasma cells, we identified the plasma cells using the monoclonal antibodies. In the work of Durak et al. [23], the FISH analysis was carried out on bone marrow cells with no plasma cell identification. Therefore, considering this we and the authors of [12] were guided by recommendations of the European Myeloma Network in the abnormal cell counting, the differences in the frequency of chromosome 13 aberrations can be related to the use of different plasmocyte isolation methods.

Besides, we would like to notice that the differences may be of an ethnic nature as well since our work presented the data from various countries of the world.

\section{Conclusion}

The present study shows the significance of identification of differential diagnostic markers of the disease for patients with CLPN, in particular, the deletion of critical regions $13 q$ for optimizing the treatment of patients. The further FISH studies, which will involve more patients with B-CLL, DLBCL and $\mathrm{MM}$, are required to find out a more comprehensive pattern of genetic changes in the long arm of chromosome 13 for the diseases prognosis in the Ukrainian patients with CLPN. 


\section{REFERENCES}

1. Fluorescence in situ hybridization (FISH) protocols and applications. Eds. Bridger JM, Volpi EV. Springer, 2010. $451 \mathrm{p}$.

2. Dal Bo M, Rossi FM, Rossi D, Deambrogi C, Bertoni F, Del Giudice I, Palumbo G, Nanni M, Rinaldi A, Kwee I, Tissino E, Corradini G, Gozzetti A, Cencini E, Ladetto M, Coletta AM, Luciano F, Bulian P, Pozzato G, Laurenti L, Forconi F, Di Raimondo F, Marasca R, Del Poeta G, Gaidano G, Foà $R$, Guarini A, Gattei V. 13q14 deletion size and number of deleted cells both influence prognosis in chronic lymphocytic leukemia. Genes Chromosomes Cancer. 2011;50(8): 633-43.

3. Rinaldi A, Mian M, Chigrinova E, Arcaini L, Bhagat G, Novak U, Rancoita PM, De Campos CP, Forconi F, Gascoyne RD, Facchetti F, Ponzoni M, Govi S, Ferreri AJ, Mollejo M, Piris MA, Baldini L, Soulier J, Thieblemont $C$, Canzonieri $V$, Gattei V, Marasca R, Franceschetti S, Gaidano G, Tucci A, Uccella $S$, Tibiletti $M G$, Dirnhofer $S$, Tripodo $C$, Doglioni $C$, Dalla Favera R, Cavalli F, Zucca E, Kwee I, Bertoni F. Genome-wide DNA profiling of marginal zone lymphomas identifies subtype-specific lesions with an impact on the clinical outcome. Blood. 2011;117(5):1595-604.

4. Scandurra M, Mian M, Greiner TC, Rancoita PM, De Campos CP, Chan WC, Vose JM, Chigrinova E, Inghirami G, Chiappella A, Baldini L, Ponzoni M, Ferreri AJ, Franceschetti S, Gaidano G, Montes-Moreno S, Piris MA, Facchetti F, Tucci A, Nomdedeu JF, Lazure T, Lambotte O, Uccella $S$, Pinotti G, Pruneri G, Martinelli G, Young KH, Tibiletti $M G$, Rinaldi A, Zucca E, Kwee I, Bertoni F. Genomic lesions associated with a different clinical outcome in diffuse large B-Cell lymphoma treated with R-CHOP-21. Br J Haematol. 2010;151(3):221-31.

5. Nelson M, Perkins SL, Dave BJ, Coccia PF, Bridge JA, Lyden ER, Heerema NA, Lones MA, Harrison L, Cairo MS, Sanger $W G$. An increased frequency of $13 \mathrm{q}$ deletions detected by fluorescence in situ hybridization and its impact on survival in children and adolescents with Burkitt lymphoma: results from the Children's Oncology Group study CCG5961. Br J Haematol. 2010;148(4):600-10.

6. Fonseca R, Bergsagel PL, Drach J, Shaughnessy J, Gutierrez $N$, Stewart AK, Morgan $G$, Van Ness B, Chesi M, Minvielle $S$, Neri A, Barlogie B, Kuehl WM, Liebisch P, Davies F, Chen-Kiang $S$, Durie BG, Carrasco R, Sezer O, Reiman T, Pilarski L, Avet-Loiseau H; International Myeloma Working Group. International Myeloma Working Group molecular classification of multiple myeloma: spotlight review. Leukemia. 2009;23(12):2210-21.

7. Eid OM, Eid MM, Kayed HF, Mahmoud WM, Mousafa SS, Ismail MM, Abdeen DM. Detection of cytogenetics abnormalities in chronic lymphocytic leukemia using FISH technique and their prognostic impact. Gulf J Oncolog. 2014;1 (15):68-75.
8. Lenz G, Wright GW, Emre NC, Kohlhammer H, Dave SS, Davis RE, Carty S, Lam LT, Shaffer AL, Xiao W, Powell J, Rosenwald A, Ott G, Muller-Hermelink HK, Gascoyne RD, Connors JM, Campo E, Jaffe ES, Delabie J, Smeland EB, Rimsza LM, Fisher RI, Weisenburger DD, Chan WC, Staudt $L M$. Molecular subtypes of diffuse large B-cell lymphoma arise by distinct genetic pathways. Proc Natl Acad Sci US A. 2008;105(36):13520-5.

9. Bogusz AM, Baxter RH, Currie T, Sinha P, Sohani AR, KutokJL, Rodig SJ. Quantitative immunofluorescence reveals the signature of active B-cell receptor signaling in diffuse large B-cell lymphoma. Clin Cancer Res. 2012;18(22):6122-35.

10. Wada M, Okamura T, Okada M, Teramura M, Masuda M, Motoji T, Mizoguchi H. Delineation of the frequently deleted region on chromosome arm 13q in B-cell non-Hodgkin's lymphoma. Int J Hematol. 2000;71(2):159-66.

11. Jekarl DW, Min CK, Kwon A, Kim H, Chae H, Kim M, Lim J, Kim Y, Han K. Impact of genetic abnormalities on the prognoses and clinical parameters of patients with multiple myeloma. Ann Lab Med. 2013;33(4):248-54.

12. Gao X, Li C, Zhang R, Yang R, Qu X, Qiu H, Xu J, Lu H, Li J, Chen $L$. Fluorescence in situ hybridization analysis of chromosome aberrations in 60 Chinese patients with multiple myeloma. Med Oncol. 2012;29(3):2200-6.

13. Biran N, Jagannath $S$, Chari A. Risk stratification in multiple myeloma, part the significance of genetic risk factors in the era of currently available therapies. Clin Adv Hematol Oncol. 2013;11(9):578-83.

14. Zhou Y, Barlogie B, Shaughnessy JD Jr. The molecular characterization and clinical management of multiple myeloma in the post-genome era. Leukemia. 2009;23(11):1941-56.

15. Oh S, Koo DH, Kwon MJ, Kim K, Suh C, Min CK, Yoon SS, Shin HJ, Jo DY, Kwak JY, Kim JS, Sohn SK, Joo YD, Eom HS, Kim SH, Kim YS, Kim C, Mun YC, Kim H, Lee DS, Lee JH; Korean Multiple Myeloma Working Party (KMMWP). Chromosome 13 deletion and hypodiploidy on conventional cytogenetics are robust prognostic factors in Korean multiple myeloma patients: web-based multicenter registry study. Ann Hematol. 2014;93(8):1353-61.

16. Swerdlow SH, Campo E, Harris NL, Jaffe ES, Pileri SA, Stein H, Thiele J, Vardiman JW. WHO Classification of tumours of haematopoietic and lymphoid tissues. World Health Organization, 2008. 439 p.

17. Glantz S. Primer of Biostatistics McGraw-Hill Education Medical; 7 edition 2011; $320 \mathrm{p}$.

18. Wolff DJ, Bagg A, Cooley LD, Dewald GW, Hirsch BA, Jacky PB, Rao KW, Rao PN; Association for Molecular Pathology Clinical Practice Committee; American College of Medical Genetics Laboratory Quality Assurance Committee. Guidance for fluorescence in situ hybridization testing in hematologic disorders. J Mol Diagn. 2007;9(2):134-43.

19. Chang YH, Park J, Kim HC, Chun HK, Kim YR, Kim M, Han K, Lee JH, Lee KH, Cho HI, Lee YS, Lee DS. Korean patients with chronic lymphocytic leukemia show the simi- 
13q Deletions detected by fluorescence in situ hybridization for diagnosis and prognosis of CLPN

lar types of chromosomal aberrations as those in Europe and North America. Leuk Res. 2006;30(6):695-9.

20. Degheidy HA, Gadalla SM, Farooqui MZ, Abbasi F, Arthur DC, Bauer SR, Wilson WH, Wiestner A, Stetler-Stevenson $M A$, Marti GE. Bcl-2 level as a biomarker for 13q14 deletion in CLL. Cytometry B Clin Cytom. 2013;84(4):237-47.

21. Caraway NP, Thomas E, Khanna A, Payne L, Zhang HZ, Lin E, Keating MJ, Katz RL. Chromosomal abnormalities detected by multicolor fluorescence in situ hybridization in fine-needle aspirates from patients with small lymphocytic lymphoma are useful for predicting survival. Cancer. 2008;114(5):315-22.

22. Havelange V, Ameye G, Théate I, Callet-Bauchu E, Mugneret F, Michaux L, Dastugue N, Penther D, Barin C, Collonge-Rame MA, Baranger L, Terré C, Nadal N, Lippert E, Laï JL, Cabrol C, Tigaud I, Herens C, Hagemeijer A, Raphael M, Libouton JM, Poirel HA; GFCH (Groupe Francophone de Cytogénétique Hématologique). Patterns of genomic aberrations suggest that Burkitt lymphomas with complex karyotype are distinct from other aggressive B-cell lymphomas with MYC rearrangement. Genes Chromosomes Cancer. 2013;52(1):81-92.

23. Durak BA, Akay OM, Sungar G, Bademci G, Aslan V, Caferler J, Ozdemir M, Cilingir O, Artan S, Gülbaş Z. Conventional and molecular cytogenetic analyses in Turkish patients with multiple myeloma. Turk J Haematol. 2012;29(2):135-42.

24. Gole L, Lin A, Chua C, Chng WJ. Modified cIg-FISH protocol for multiple myeloma in routine cytogenetic laboratory practice. Cancer Genet. 2014;207(1-2):31-4.

25. Wolff DJ, Bagg A, Cooley LD, Dewald GW, Hirsch BA, Jacky PB, Rao KW, Rao PN; Association for Molecular Pathology Clinical Practice Committee; American College of Medical Genetics Laboratory Quality Assurance Committee. Guidance for fluorescence in situ hybridization testing in hematologic disorders. J Mol Diagn. 2007;9(2):134-43.

\section{Діагностичне і прогностичне значення визначення 13q делецій за допомогою флуоресцентної in situ гібридизації}

В. В. Сітько, Ж. А. Мішаріна, Ж. М. Мінченко, Л. О. Полубень, О. О. Дмитренко, Ю. О. Сілаєв, Н. І. Костюкова, О. В. Ткаченко, А. О. Товстоган, В. М. Полянська, Л. О. Ляшенко, В. Г. Бебешко

Мета. Визначення делецій довгого плеча хромосоми 13 у хворих на хронічну лімфоцитарну лейкемію, дифузну крупноклітинну В-лімфому і множинну мієлому для надання прогностичних оцінок щодо перебігу цих підваріантів хронічних лімфопроліферативних новоутворень (ХЛПН), та своєчасного виявлення резистентних до терапії випадків і рецидивів ХЛПН. Методи. Досліджено 115 препаратів клітин кісткового мозку хворих на ХЛПН. Флуоресцентну in situ гі- бридизацію проводили з використанням комерційної проби Vysis LSI D13S319 (13q14.3) Spectrum Orange / Vysis LSI 13 q34 Spectrum Green FISH probe kit (Abbott Molecular, США). Результати. При молекулярно-цитогенетичних дослідженнях наших пацієнтів, делеції 13q були виявлені в 38 \% випадків ХЛПН. Також, наведений опис клінічного випадку, де показано, що наявність делецій $13 q$ разом з іншими цитогенетическими абераціями значно погіршує прогноз захворювання. Висновки. Аналіз делецій довгого плеча хромосоми $13 є$ важливим діагностичним і прогностичним критерієм, який дозволить оптимізувати лікування хворим на ХЛПН.

Кл юч о в і с л о в а: хронічні лімфопроліферативні новоутворення, хронічна лімфоцитарна лейкемія, дифузна крупноклітинна В-лімфома, множинна мієлома, 13q делеція, флуоресцентна in situ гібридизація.

\section{Диагностическое и прогностическое значение определения 13q делеций с помощью флуоресцентной in situ гибридизации}

В. В. Ситько, Ж. А. Мишарина, Ж. Н. Минченко, Л. А. Полубень, Е. А. Дмитренко, Ю. О. Силаев, Н. И. Костюкова, О. В. Ткаченко, А. А. Товстоган, В. М. Полянская, Л. А. Ляшенко, В. Г. Бебешко

Цель. Определение делеций длинного плеча хромосомы 13 у больных с хронической лимфоцитарной лейкемией, диффузной крупноклеточной В-лимфомой и множественной миеломой для прогностической оценки течения этих подвариантов хронических лимфопролиферативных новообразований (ХЛПН), и своевременного выявления резистентных к терапии случаев и рецидивов ХЛПН. Методы. Исследовано 115 препаратов клеток костного мозга больных с ХЛПН. Флуоресцентную in situ гибридизацию проводили с использованием коммерческой пробы Vysis LSI D13S319 (13q14.3) Spectrum Orange/ Vysis LSI 13q34 Spectrum Green FISH probe kit (Abbott Molecular, США). Результаты. При молекулярно-цитогенетическом исследовании препаратов субстратных клеток наших пациентов, делеции 13q были обнаружены в 38 \% случаев ХЛПН. Также, представлен клинический случай, где показано, что наличие делеций $13 q$ вместе с другими цитогенетическими аберрациями значительно ухудшает прогноз заболевания. Выводы. Анализ делеций длинного плеча хромосомы 13 является важным диагностическим и прогностическим критерием, который позволит оптимизировать лечение больным на ХЛПН.

Ключевы е сл в а: хронические лимфопролиферативные новообразования, хроническая лимфоцитарная лейкемия, диффузная крупноклеточная В-лимфома, множественная миелома, $13 q$ делеция, флуоресцентная in situ гибридизация.

Received 17.05.2015 